\title{
High-performance aqueous rechargeable batteries based on zinc anode and $\mathrm{NiCo}_{2} \mathrm{O}_{4}$ cathode
}

\author{
JUN WANG ${ }^{1,2}$, ZHIJUN JIA ${ }^{2, *}$, SONGBO LI ${ }^{1}$, YI WANG ${ }^{2}$, WEI GUO ${ }^{3}$ and TAO QI $^{2}$ \\ ${ }^{1}$ School of Chemistry and Chemical Engineering, Inner Mongolia University of Science and Technology, \\ Baotou 014000, China \\ ${ }^{2}$ National Engineering Laboratory for Hydrometallurgical Cleaner Production Technology, \\ Institute of Process Engineering, Chinese Academy of Sciences, Beijing 100190, China \\ ${ }^{3}$ Beijing Municipal Human Resources and Social Security Bureau, Beijing 100050, China
}

MS received 23 December 2014; accepted 2 June 2015

\begin{abstract}
A new aqueous $\mathrm{Zn}-\mathrm{NiCo}_{2} \mathrm{O}_{4}$ rechargeable battery system with a high voltage, consisting of $\mathrm{NiCo}_{2} \mathrm{O}_{4}$ as cathode and metal $\mathrm{Zn}$ as anode, is proposed for the first time. It is cheap and environmental friendly, and its energy density is about $202.8 \mathrm{Wh} \mathrm{kg}^{-1}$. The system still maintains excellent capacity retention of about $85 \%$ after 100 full cycles at a current rate of $2 \mathrm{~A} \mathrm{~g}^{-1}$ between 1.5 and $1.95 \mathrm{~V}$. This work not only provides a new battery system but also shows promise for application in large-scale energy storage for its low cost, good cycling and environmental friendliness.
\end{abstract}

Keywords. Rechargeable battery; aqueous electrolyte; $\mathrm{NiCo}_{2} \mathrm{O}_{4}$ cathode; $\mathrm{Zn}$ anode; energy density.

\section{Introduction}

The eminent global energy crisis and growing ecological concerns have led to intensive developments in the application of clean and renewable energies, as well as green transportations such as electric and hybrid electric vehicles. ${ }^{1}$ All these applications demand low cost, safe and environment-friendly energy storage system. Battery is the most versatile means for storing electricity in the form of chemical energy. Lithium ion batteries have highest energy and highest power densities among rechargeable batteries. ${ }^{2}$ But there still exists some disadvantages of high cost and flammable nature. On the other hand, traditional aqueous batteries are cost effective and safe but limited in energy density. ${ }^{2}$ Therefore, new aqueous rechargeable battery systems have been attracted great attention in recent years for their good safety, high ionic conductivity and the low cost of aqueous electrolytes.

Aqueous rechargeable batteries mainly include aqueous rechargeable lithium batteries and aqueous rechargeable sodium and potassium batteries. ${ }^{3}$ All these energy storage systems provide several advantages over the traditional energy storage systems, such as low cost, long cycle life, environmental friendliness and safety. The above characteristics are very important for these systems in storing energy for electrical grids connected with intermittent energy sources such as solar, wind and hydropower. It is

\footnotetext{
*Author for correspondence (zjjia@ipe.ac.cn)
}

also important to lower the cost and meet the stringent safety requirements of batteries for pure electric vehicles. The challenges to significantly increase the specific output power and energy density of batteries urgently need to be solved. ${ }^{3}$

Herein, a safe and environmental-friendly $\mathrm{Zn}-\mathrm{NiCo}_{2} \mathrm{O}_{4}$ rechargeable battery in aqueous alkaline solution by taking advantage of $\mathrm{NiCo}_{2} \mathrm{O}_{4}$ as cathode-active material and metal $\mathrm{Zn}$ as anode-active material is presented. The feasibility of this battery is ensured by using a mixed $\mathrm{LiOH} / \mathrm{KOH}$ aqueous electrolyte with an indispensable alkalinity for the electrode reaction of $\mathrm{NiCo}_{2} \mathrm{O}_{4}$ and $\mathrm{Zn}$ electrode.

\section{Experimental}

\subsection{Preparation of $\mathrm{NiCO}_{2} \mathrm{O}_{4}$}

In a typical procedure, $0.002 \mathrm{~mol} \mathrm{Ni}\left(\mathrm{NO}_{3}\right)_{2} \cdot 6 \mathrm{H}_{2} \mathrm{O}$ and $0.004 \mathrm{~mol} \mathrm{Co}\left(\mathrm{NO}_{3}\right)_{2} \cdot 6 \mathrm{H}_{2} \mathrm{O}$ were dissolved in $40 \mathrm{ml} \mathrm{DI}$ water sequentially. Then the solution was stirred for half an hour at room temperature to form a black solution, followed by a drop-by-drop addition of $28 \% \mathrm{NH}_{3} \cdot \mathrm{H}_{2} \mathrm{O}$ solution until its $\mathrm{pH}$ reached 9 . Being kept still for $5 \mathrm{~h}$, the obtained precipitate was filtered, washed with water and ethanol several times to remove the surfactant and the residual ions, and dried at $80^{\circ} \mathrm{C}$ for $12 \mathrm{~h}$ in air. Finally, the precursor was annealed in air at $300^{\circ} \mathrm{C}$ for $3 \mathrm{~h}$ with a slow heating rate of $1^{\circ} \mathrm{C} \min ^{-1}$ in order to obtain $\mathrm{NiCo}_{2} \mathrm{O}_{4}$ nanostructure. 


\subsection{Characterization}

The structure and composition of synthesized product was characterized by powder X-ray diffraction (XRD) obtained with a Philips X-ray diffratometer equipped with $\mathrm{CuK} \alpha$ radiation $(\lambda=1.5418 \AA)$. The angular resolution in $2 \theta$ scans was $0.02^{\circ}$ over a $2 \theta$ range of $15-90^{\circ}$.

The working electrodes were prepared by coating slurries of active material with acetylene black and polyvinylidene fluoride $(80: 10: 10)$ in dimethyl sulphoxide on carbon plates. After drying at $100^{\circ} \mathrm{C}$ for $12 \mathrm{~h}$, the electrodes were used directly. All the electrochemical measurements were performed with a CHI760D workstation by using a three-electrode cell with Pt sheet as the counter electrode and a $\mathrm{Hg} / \mathrm{HgO}$ electrode as the reference electrode. Cyclic voltammogram (CV) was measured between 0.4 and $1.6 \mathrm{~V}$ in an alkaline solution containing $3 \mathrm{~mol} \mathrm{l}^{-1}$ $\mathrm{KOH}$ and $1 \mathrm{~mol}^{-1} \mathrm{LiOH}$. The charge and discharge curves of the prepared $\mathrm{NiCo}_{2} \mathrm{O}_{4}$ at different rates were measured between 1.5 and $1.95 \mathrm{~V}$ with a two electrodes system, in which $\mathrm{Zn}$ metal was used as the counter electrode. The performance was evaluated by 100 full cycles at a current rate of $2 \mathrm{~A} \mathrm{~g}^{-1}$.

\section{Results and discussion}

The XRD pattern of the prepared $\mathrm{NiCo}_{2} \mathrm{O}_{4}$ powder is shown in figure 1a. As shown in figure 1a, eight characteristic diffraction peaks appeared, which can be readily indexed to the planes of the cubic $\mathrm{NiCo}_{2} \mathrm{O}_{4}$ phase (JCPDS card no. 20-0781). ${ }^{4}$ It is worth mentioning that the pattern shows a weak crystalline state and no other peaks are observed, which effectively confirms the purity of the obtained $\mathrm{NiCo}_{2} \mathrm{O}_{4}$ phase.

Figure 2 shows $\mathrm{CVs}$ of the zinc metal and the obtained $\mathrm{NiCo}_{2} \mathrm{O}_{4}$ at a scan rate of $2 \mathrm{mV} \mathrm{s}^{-1}$ in a mixed $\mathrm{Li}(\mathrm{OH}) /$

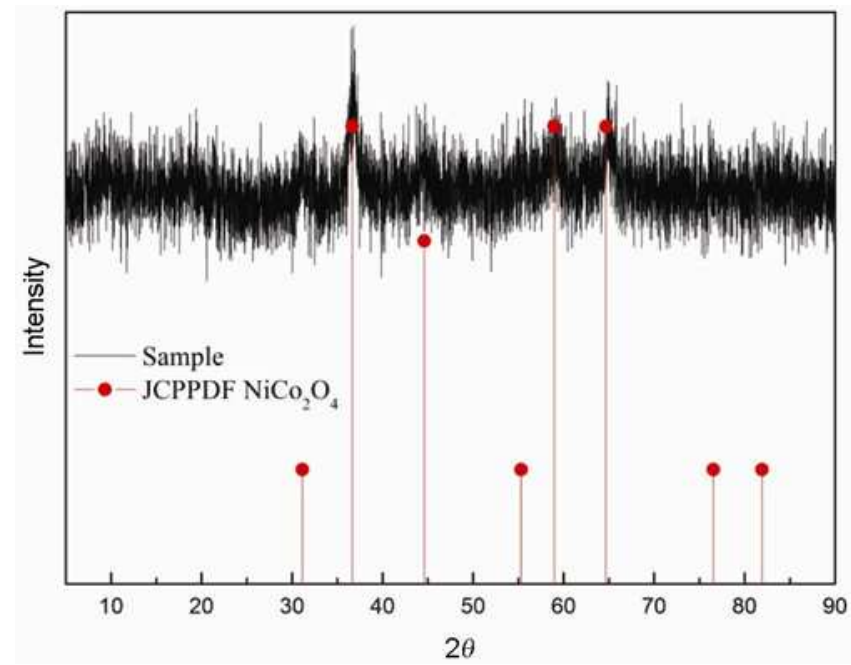

Figure 1. Representative side-angle XRD patterns of $\mathrm{NiCo}_{2} \mathrm{O}_{4}$ powder.
$\mathrm{KOH}$ aqueous electrolyte. In the case of the prepared $\mathrm{NiCo}_{2} \mathrm{O}_{4}$, the oxidation and reduction potential peaks can be observed at 1.1 and $0.9 \mathrm{~V}(v s . \mathrm{Hg} / \mathrm{HgO})$, respectively, accompanied simultaneously with corresponding proton insertion/extraction reactions. ${ }^{5-7}$ In the case of $\mathrm{Zn}$, the pair of reversible redox peaks appears at -0.54 and $\sim-0.4 \mathrm{~V}$ due to $\mathrm{Zn}$ dissolution/deposition, respectively. Since there is a potential difference between $\mathrm{Zn}$ and $\mathrm{NiCo}_{2} \mathrm{O}_{4}$, they can be assembled into a battery system whose redox reaction during charge and discharge process can be schematically shown as in figure 3 a.

The charge and discharge curves of the prepared $\mathrm{NiCo}_{2} \mathrm{O}_{4}$ at different rates using $\mathrm{Zn}$ metal as the counter electrode are shown in figure $3 \mathrm{~b}$. At the charge rate of $1 \mathrm{~A} \mathrm{~g}^{-1}$, it can be seen that the average charge and discharge voltage plateaus are about 1.8 and $1.7 \mathrm{~V}$, which is inconsistent with the above $\mathrm{CV}$ results. The reversible capacity is $112 \mathrm{mAh} \mathrm{g}^{-1}$ based on the $\mathrm{NiCo}_{2} \mathrm{O}_{4}$-positive electrode. The energy density of $\mathrm{Zn}$ metal is up to $825 \mathrm{mAh} \mathrm{g}^{-1}$, so the energy density of this battery system is restricted by the positive electrode. The reversible capacities of $\mathrm{NiCO}_{2} \mathrm{O}_{4}$ are $82.5,40.1$ and $15.3 \mathrm{mAh} \mathrm{g}^{-1}$ at 2,5 and $10 \mathrm{~A} \mathrm{~g}^{-1}$, respectively. This suggests that the
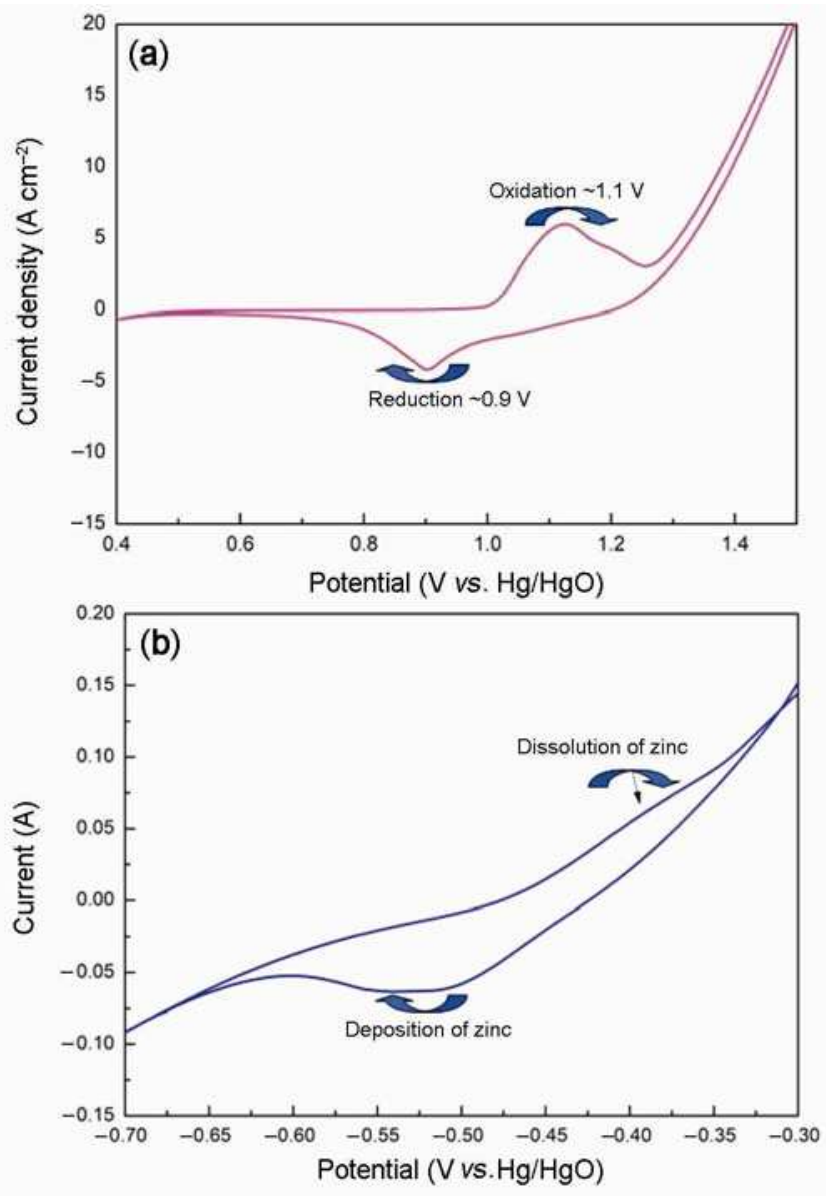

Figure 2. Typical CVs of the (a) zinc metal and (b) $\mathrm{NiCo}_{2} \mathrm{O}_{4}$ at a scan rate of $2 \mathrm{mV} \mathrm{s}^{-1}$. 


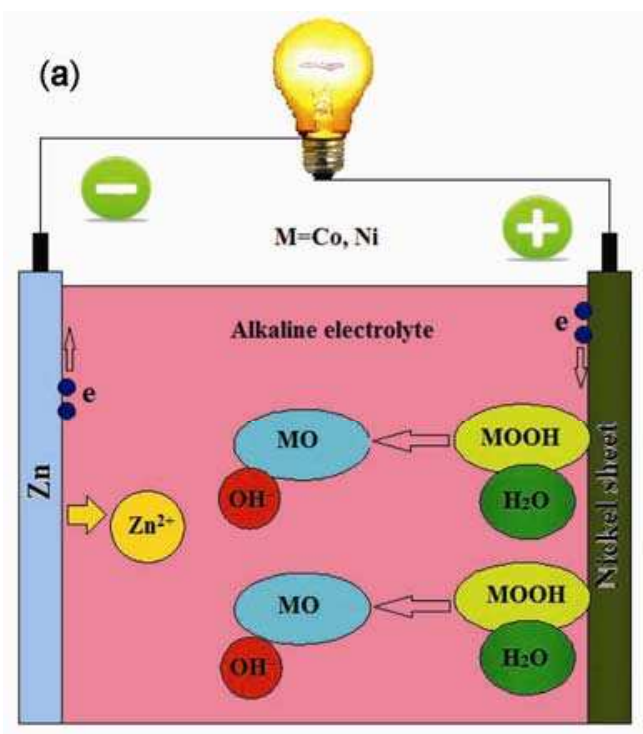

(b)

(c)

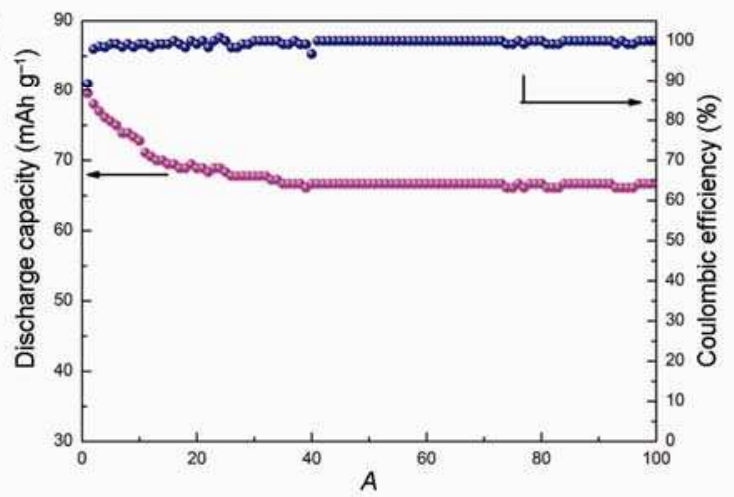

Figure 3. (a) Schematic representation of the electrochemical reaction process of the $\mathrm{Zn}-\mathrm{NiCo}_{2} \mathrm{O}_{4}$ prototype cell; (b) charge and discharge curves of the $\mathrm{NiCo}_{2} \mathrm{O}_{4}$ at different rates using $\mathrm{Zn}$ metal as the counter electrode and (c) cycling performance of the $\mathrm{Zn} / / \mathrm{NiCo}_{2} \mathrm{O}_{4}$ prototype cell at $2 \mathrm{~A} \mathrm{~g}^{-1}$.

aqueous rechargeable battery can be charged and discharged very rapidly, which can meet the rapid charge of power supply and demand from the grids. Battery is based on the solid phase reaction, the large specific surface area will be beneficial for the further improvement of the battery system performance.

The cycling performance of the $\mathrm{Zn}-\mathrm{NiCo}_{2} \mathrm{O}_{4}$ rechargeable battery in aqueous alkaline electrolyte at $2 \mathrm{~A} \mathrm{~g}^{-1}$ based on $\mathrm{NiCo}_{2} \mathrm{O}_{4}$ is illustrated in figure 3c. Obviously, the prototype cell shows an excellent cycling stability. At the initial 40 cycles, the discharge capacity decreases from 79 to $67 \mathrm{mAh} \mathrm{g}^{-1}$, and then keeps at a stable value about $67 \mathrm{mAh} \mathrm{g}^{-1}$, maintaining excellent capacity retention of about $85 \%$. At the first cycle, the Columbic efficiency is about $89 \%$ and then increases to about $99 \%$ at the later stage.

From the above, it can be seen clearly that the positive electrode of the prepared $\mathrm{NiCo}_{2} \mathrm{O}_{4}$ can work very well. In addition, the negative zinc electrode has a very high capacity. Both electrode materials are very cheap and have rich natural sources. ${ }^{8,9}$ For all these characterizations, such as safe, low cost and environmentally friendly, this battery system can be a good candidate for being a power source for smart grids to store renewable energies such as solar, wind and tide. Moreover, it can also be a choice to level the valley and peak of power supply of the grids. ${ }^{10,11}$

\section{Conclusion}

In summary, an aqueous rechargeable battery system by integrating $\mathrm{NiCo}_{2} \mathrm{O}_{4}$ as cathode, metal $\mathrm{Zn}$ as anode and mixed aqueous $\mathrm{LiOH} / \mathrm{KOH}$ aqueous solution as electrolyte was fabricated. It is a feasible strategy to combine two different electrode reaction mechanisms in aqueous alkaline electrolyte. Importantly, the fabricated $\mathrm{Zn}-\mathrm{NiCo}_{2} \mathrm{O}_{4}$ alkaline rechargeable battery has a high operation voltage of over $1.7 \mathrm{~V}$ and the energy density can have values of up to $202.8 \mathrm{Wh} \mathrm{kg}^{-1}$ based on the positive electrode material. The system still maintains excellent capacity retention of about $85 \%$ after 100 full cycles at a current rate of $2 \mathrm{~A} \mathrm{~g}^{-1}$ between 1.5 and $1.95 \mathrm{~V}$. This work not only provides a new low-cost battery system but also shows 
promise for application in large-scale energy storage for its low cost, good cycling and environmental friendliness.

\section{Acknowledgement}

We are grateful for the financial support by One Hundred Talent Program of Chinese Academy of Sciences, as well as by the NSFC (51302264) of China.

\section{References}

1. Yan J, Wang J, Liu H, Bakenov Z, Gosselink D and Chen P 2012 J. Power Sources 216222

2. Zhang B H, Liu Y, Wu X W, Yang Y Q, Chang Z, Wen Z B and Wu Y P 2014 Chem. Commun. 501209
3. Chang Z, Yang Y Q, Li M X, Wang X W and Wu Y P 2014 J. Mater. Chem. A 210739

4. Cai F, Kang Y R, Chen H Y, Chen M H and Li Q W 2014 J. Mater. Chem. A 211509

5. Wang G X, Zhong S, Bradhurst D H, Dou S X and Liu H K 1998 J. Power Sources 74198

6. Liu S, Pan G L, Yan N F and Gao X P 2010 Energy Environ. Sci. 31732

7. Gong M, Li Y G, Zhang H B, Zhang B, Zhou W, Feng J, Wang H L, Liang Y Y, Fan Z J, Liu J and Dai H J 2014 Energy Environ. Sci. 72025

8. Gao X P, Yao S M, Yan T Y and Zhou Z 2009 Energy Environ. Sci. 2502

9. Wang Y M, Zhao D D, Zhao Y Q, Xu C L and Li H L 2012 RSC Adv. 21074

10. Wang R J and Yang Z H 2013 RSC Adv. 319924

11. Tang W, Liu L L, Zhu Y S, Sun H, Wu Y P and Zhu K 2012 Energy Environ. Sci. 56909 